\title{
Palladium Mediated Highly Regio- and Stereoselective Intermolecular $\beta$-Arylation on Allylic Alcohols: Synthesis of Functionalized Allylic Alcohols
}

\author{
J. Krishna, A. Gopi Krishna Reddy, B. Venkat Ramulu, L. Mahendar, and G. Satyanarayana* \\ Indian Institute of Technology (IIT) Hyderabad, Ordnance Factory Estate Campus, Yeddumailaram - 502 205, Medak District, Andhra \\ Pradesh, India \\ Fax: +91(40) 23016032 \\ E-mail: gvsatya@iith.ac.in \\ Received: The date will be inserted once the manuscript is accepted. \\ Dedicated to Prof. Dr. Martin E Maier.
}

\begin{abstract}
An efficient and highly regio- and stereoselctive Pdcatalyzed $\beta$-arylation method for the formation of $\beta$-arylallylic alcohols, employing aryl iodides, 1-bromo-2-iodobenzenes and 2 -bromobezaldehydes as coupling partners, is presented. The products $\beta$-arylallylic alcohol formed in this Pd-catalyzed transformation is unexpected under conventional Jeffery's conditions without the assistance of silver salt. It is understood that the reaction is substrate controlled and depends on the size or nature of the substituent at the ortho-position on the aromatic ring of the allylic alcohol part, for selective formation of the product.
\end{abstract}

Key words: Pd-catalysis; $\beta$-Arylation; Mizoroki-Heck; allylic alcohols; $\beta$-Carbonyls.

Transition-metal catalysis is a powerful tool that permits $\mathrm{C}-\mathrm{C}$ bond forming reactions quite efficiently. In this context, palladium is one of the most used metals suitable for oxidations, reductions and many efficient cross-coupling reactions. Among these Heck type reaction is one of the most useful reactions mediated by palladium. ${ }^{1,2}$ In this context, Heck ${ }^{3}$ and Chalk $^{4}$ independently but simultaneously reported Pdcatalyzed transformations of allylic alcohols with aryl halides coupling partners which resulted in the formation of $\beta$-arylcarbonyls. Subsequently, Jeffery ${ }^{5}$ developed a method based on the catalyst directed Heck-type reaction that either leads to formation of $\beta$ aryl (or alkenyl) carbonyls or to selective $\beta$-aryl (or alkenyl) allylic alcohols. Formation of latter was controlled by the use of silver salts (either AgOAc or $\mathrm{Ag}_{2} \mathrm{CO}_{3}$ ) as additive to the catalytic system, which was crucial for the controlled formation of $\beta$-aryl (or alkenyl) allylic alcohols, by preventing further double bond isomerization. Subsequently, many useful applications of Pd-catalyzed coupling of allylic alcohols, homoallylic and homologous ene-alcohols even with aryl halides, to yield arylcarbonyls and also to arylallylic alcohols have been reported in the literature. ${ }^{6-12}$ Interestingly, Jeffery's conditions were also amenable to 1-bromo-2-iodobenzenes as coupling partners, with the resulting products having applications. ${ }^{9}$

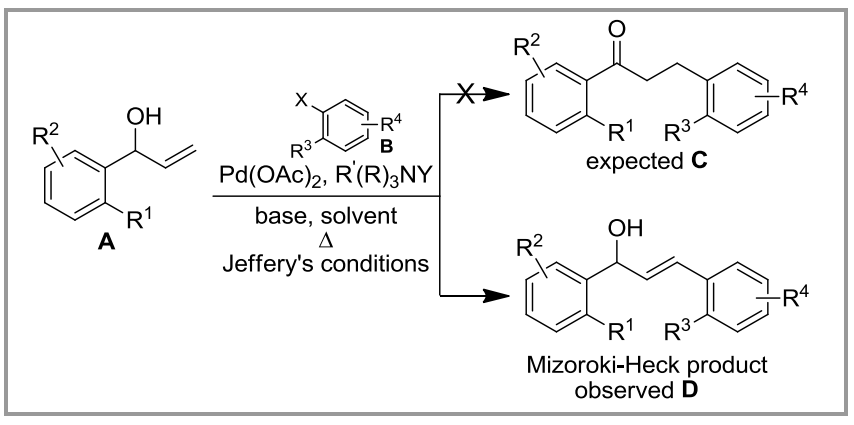

Scheme 1

Herein we report a concise, practical, and highly regioand stereoselective method for the synthesis of $\beta$ arylallylic alcohols based on a hitherto unexplored, substrate controlled intermolecular Pd-mediated $\beta$ arylation coupling using conventional Jeffery's conditions under which normally $\beta$-arylcarbonyls are formed, without the assistance of silver salt restricted double bond isomerization, leading predominately to the corresponding $\beta$-arylallylic alcohols.

Table 1. Optimization of reaction conditions towards the synthesis of $\beta$-arylallylic alcohol 3ab.

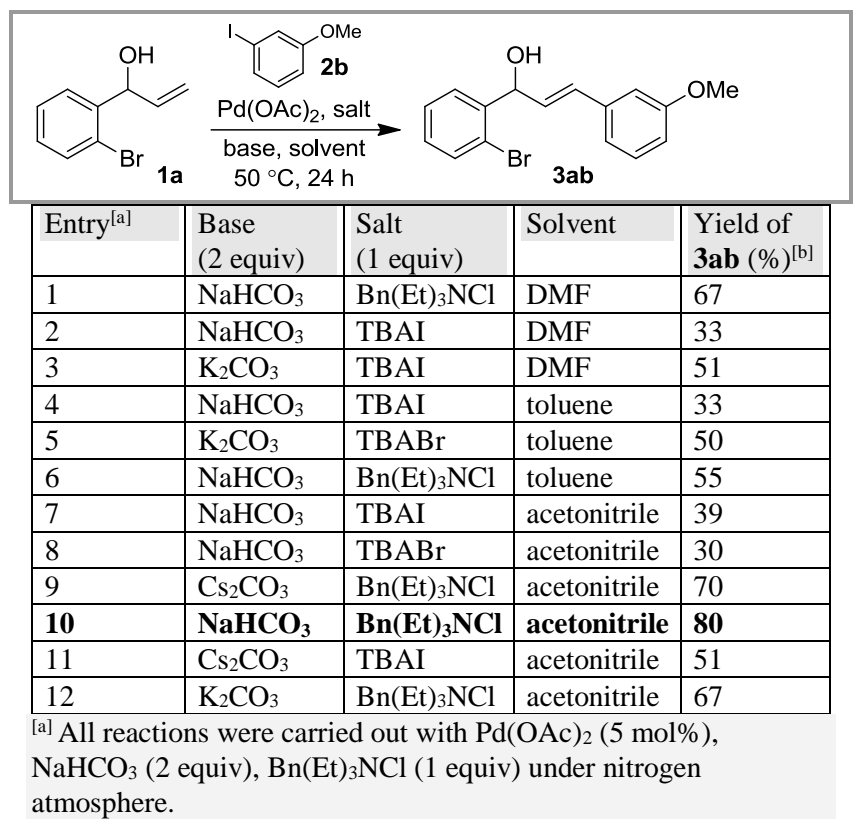


[b] Isolated yields of chromatographically pure products; for compounds 3 the first letter refers to the allylic alcohol part (1a) whereas the second letter indicates the aromatic ring coming from the aryl iodide $\mathbf{2 b}$.

In the course of our investigations on Pd-catalysis for the synthesis of dihydrochalocones, we envisioned the Pd-catalyzed Jeffery's conditions would be ideally suited for the formation of desired dihydrochalcone $\mathbf{C}$ using allylic alcohol $\mathbf{A}$ and arylhalide $\mathbf{B}$ as coupling partners.

\section{Table 2. Pd-catalyzed reaction of $\mathbf{1 a - c}$ with aryl iodides $\mathbf{2} \mathbf{a}-\mathbf{d}$ to} give 3aa-cc.
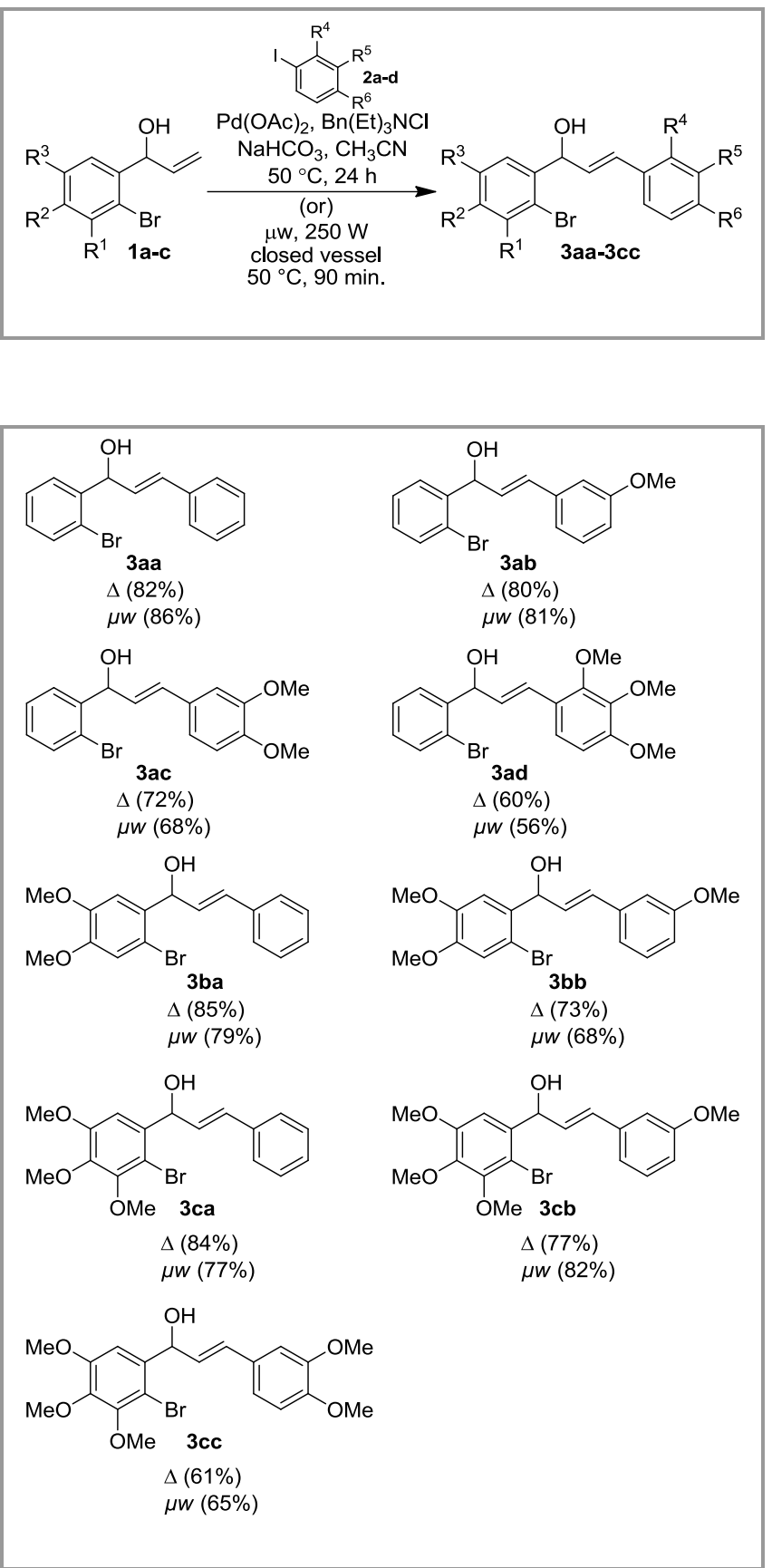

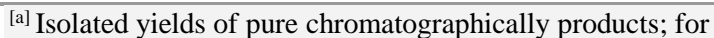
compounds 3 the first letter refers to the allylic alcohol part (1a-1c) whereas the second letter indicates the aromatic ring coming from the aryl iodides $\mathbf{2} \mathbf{a}-\mathbf{2 d}$.
Much to our surprise, under Jeffery's conditions, the only product isolated, was the $\beta$-arylallylic alcohol D (Scheme 1), even though, recently Heck-type bond isomerization was reported on substrates without ortho-substituents on the aromatic ring of the allylic alcohol, by which $\beta$-arylcarbonyls were yielded. ${ }^{13}$ We presumed that the substituent present at the orthoposition to the aromatic ring is crucial to make the entire aryl moiety bulky enough to restrict the rotation around the $\mathrm{C}-\mathrm{C}$ bond of the $\mathrm{PdCH}-\mathrm{CH}(\mathrm{OH}) \mathrm{Ar}$ intermediate, thus suppressing the enol formation, which ultimately would lead to the $\beta$-arylallylic alcohol. To understand well the scope and limitations of the method and to explore further whether it is specific to our substrate, we attempted to optimize the reaction conditions. Thus, the desired allylic alcohols $\mathbf{1}$ were easily prepared in excellent yields, from orthosubstituted-benzaldehydes (see supporting information) using vinylmagnesium bromide.

To further understand the factors that control the formation of the $\beta$-arylallylic alcohol and to delineate the scope of the observed transformation we tried to optimize reaction conditions for coupling of various substrates.

With the allylic alcohol 1a in hand, we studied the key Pd-mediated coupling with aryl iodide $\mathbf{2 b}$, under conventional Jeffery's conditions $\left[\mathrm{Pd}(\mathrm{OAc})_{2}\right.$, $\mathrm{Bn}(\mathrm{Et})_{3} \mathrm{NCl}, \mathrm{NaHCO}_{3}, \mathrm{DMF}, 50{ }^{\circ} \mathrm{C}, 24 \mathrm{~h}$ ], furnishing the $\beta$-arylallylic alcohol 3ab, in good yield $67 \%$ (entry 1, Table 1), while reaction with TBAI in place of $\mathrm{Bn}(\mathrm{Et})_{3} \mathrm{NCl}$,furnished the product with inferior yield $33 \%$ (entry 2, Table 1). Switching the base to $\mathrm{K}_{2} \mathrm{CO}_{3}$ in presence of TBAI furnished the product $\mathbf{3 a b}$ in moderate yield 51\% (entry 3, Table 1). Changing the solvent to toluene and bases to either $\mathrm{NaHCO}_{3}$ or $\mathrm{K}_{2} \mathrm{CO}_{3}$ furnished the product $\mathbf{3 a b}$ in poor to moderate yields (entries 4, 5, and 6, Table 1). Change of solvent to acetonitrile and use of quaternary ammonium salts such as TBAI or TBAB, gave lower yields (entries 7 and 8 , Table 1). The reaction with $\mathrm{Cs}_{2} \mathrm{CO}_{3} /$ TBAI and $\mathrm{K}_{2} \mathrm{CO}_{3} / \mathrm{Bn}(\mathrm{Et})_{3} \mathrm{NCl}$ furnished the product $\mathbf{3 a b}$ with improved yields of $51 \%$ and $67 \%$, respectively (entries 11 and 12, Table 1). The combination of $\mathrm{Cs}_{2} \mathrm{CO}_{3}$ and $\mathrm{Bn}(\mathrm{Et})_{3} \mathrm{NCl}$ in acetonitrile further improved yield $(70 \%)$ of the product 3ab (entry 9, Table 1). Finally, just changing the solvent from DMF to acetonitrile and keeping all other parameters constant, was found to be the best optimized condition and furnished the product 3ab with a yield of $80 \%$ (entry 10, Table 1). Interestingly, when these optimized conditions were used in the microwave assisted (closed vessel, power: $250 \mathrm{~W}$, temperature: $50^{\circ} \mathrm{C}$, time: $90 \mathrm{~min}$.) reaction, the olefin 1a was smoothly transformed to same product 3ab in comparable yields. 

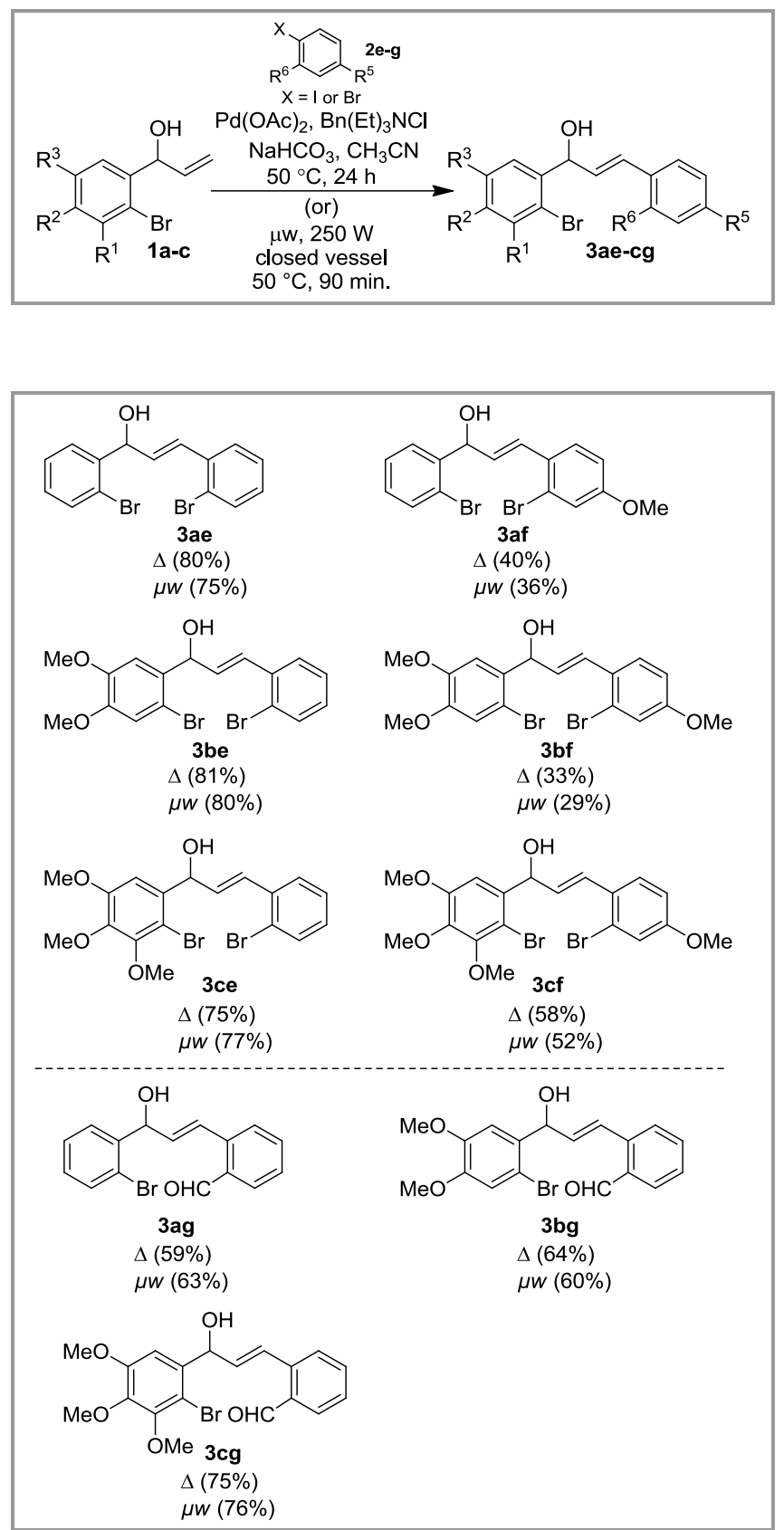

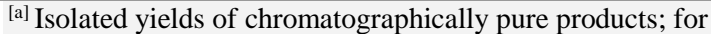
compounds 3 the first letter refers to the allylic alcohol part (1a-1c) whereas the second letter indicates the aromatic ring coming from the aryl halides $\mathbf{2 e - 2 g}$.

After optimizing the reaction conditions, the generality of the reaction was established by $\mathrm{Pd}$-catalyzed reaction of allylic alcohols $\mathbf{1}$ a-c with aryl iodides $\mathbf{2 a - d}$ to give the $\beta$-arylallylic alcohols 3aa-3cc, using both conventional and microwave conditions, and the results are summarised in Table 2.

After successful accomplishment of $\beta$-arylallylic alcohols 3aa-3cc, we turned our attention to check the scope and limitation of the method. Hence, Pd-catalysis with 1-bromo-2-iodobenzenes 2e-f on allylic alcohols 1a-c was also investigated.

In general, the results were quite consistent as to those observed in the case of aryl iodides $\mathbf{2 a - d}$, and furnished the products 3ae-cf in good yields. The only exception was in the case of 2-bromo-1-iodo-4-methoxybenzene 2f where the product was formed in poor yields (Table 3 ). Furthermore, to study the generality of this method, the reaction of $\mathbf{1 a - c}$ with 2-bromobenzaldehyde $\mathbf{2 g}$ as coupling partner was also carried out. Gratifyingly, under optimized conditions the corresponding products 3ag-cg were obtained in good yields (Table 3 ). The unusual chemoselectivity in these cases can be attributed the electron withdrawing nature of the aldehyde moiety of 2-bromobenzaldehyde $\mathbf{2 g}$ which makes the aromatic ring more reactive towards the $\mathrm{Pd}$ catalyst, for formation of aryl-palladium inserted intermediate. Finally, we studied substrates with orthomethyl and ortho-methoxyl groups in place of bromine atom on aromatic ring of the allylicalcohol 1. Even in these cases the alcohol products 3da-ef were obtained as the major products along with the ketones 4da-ff. The formation of the ketones 4da-ef is perhaps, due to the smaller size of these ortho-substituents when compared to that of bromine (Table 4). The high selectivity for the formation of allylic alcohols 3 in case of ortho-bromosubstituent over methoxy and methyl substituents can be renationalized based on bond length and polarization effects. Presumably, because of longer $\mathrm{C}$-Br bond length $(1.94 \AA)$ than $\mathrm{C}-\mathrm{C}(1.54 \AA)$ and $\mathrm{C}-\mathrm{O}$ $(1.43 \AA$ ) bond lengths, bromine resides little away from aromatic ring and closure to $\mathrm{Pd}$-species at $\mathrm{C}-2$, as a result might exert more steric hindrance and hence restrict the rotation about $\mathrm{C}_{1}-\mathrm{C}_{2}$ bond (Scheme 2) or due to it's high electron polarizability and ligation ability, can complex with Pd-species at C-2 carbon and could restrict the rotation and therefore affords the allylic alcohol $\mathbf{3}$ as a major product.

A possible mechanistic path can be reasoned as shown in Scheme 2. It appears that the addition of the initially formed aryl palladium species $\mathbf{E}$ to the double bond of the allylic alcohol $\mathbf{A}$ gives both the $s y n-(\mathbf{F})$ and antiintermediates $(\mathbf{G})$ with respect to the hydroxyl function. Even though, syn- $\beta$-hydride-PdX elimination in the case of intermediate $\mathbf{G}$ seems possible, this process might be restricted due to the bulky nature of the benzylic alcohol part. In addition $\mathrm{C}_{1}-\mathrm{C}_{2}$ bond rotation could be restricted in the right half of both intermediates $\mathbf{F}$ and $\mathbf{G}$, respectively. Now, the possible rotation of $120^{\circ}$ around $\mathrm{C}_{2}-\mathrm{C}_{3}$ bond of the left hand part of the intermediates $\mathbf{F}$ and $\mathbf{G}$, towards the direction of minimal eclipsed interaction leads to the formation of intermediates $\mathbf{H}$ and $\mathbf{I}$, respectively. Finally, syn- $\beta$ hydride-PdX elimination from both $\mathbf{H}$ and $\mathbf{I}$ yields the same allylic alcohol as product D (ca. Scheme 1) and completes the catalytic cycle. 
In summary, we have developed a highly regio- and stereoselective Pd-catalyzed $\beta$-arylation on allylic alcohols using aryl iodides, 1-bromo-2-iodobenzenes and 2-bromobenzaldehydes as coupling partners. The observation was unexpected under conventional Jeffery's conditions without silver salt assistance. The method is efficient and functioned smoothly on a variety of electron rich and electron deficient aromatic systems and lead to the products with dense functionality on aromatic rings. Furthermore, this method may be useful for the synthesis of different flavonoid derivatives.

\section{Acknowledgment}

Financial support by the Department of Science and Technology [(DST), CHE/2010-11/006/DST/GSN], New Delhi and Indian Institute of Technology (IIT) Hyderabad is gratefully acknowledged. We thank Dr. S. J. Gharpure for his valuable suggestions. J.K., A.G.K., B.V.R., and L.M. thank CSIR, New Delhi, for the award of research fellowship.

Table 4. Pd-catalyzed reaction of $\mathbf{1 d - e}$ with aryl iodides $\mathbf{2 a - c}$, bromo-iodobenzene $\mathbf{2 e - f}$, and 2-bromobenzaldehyde $\mathbf{2 g}$ to generate $\mathbf{3 d a}-\mathbf{3 e f}$ and 4da-4ef.
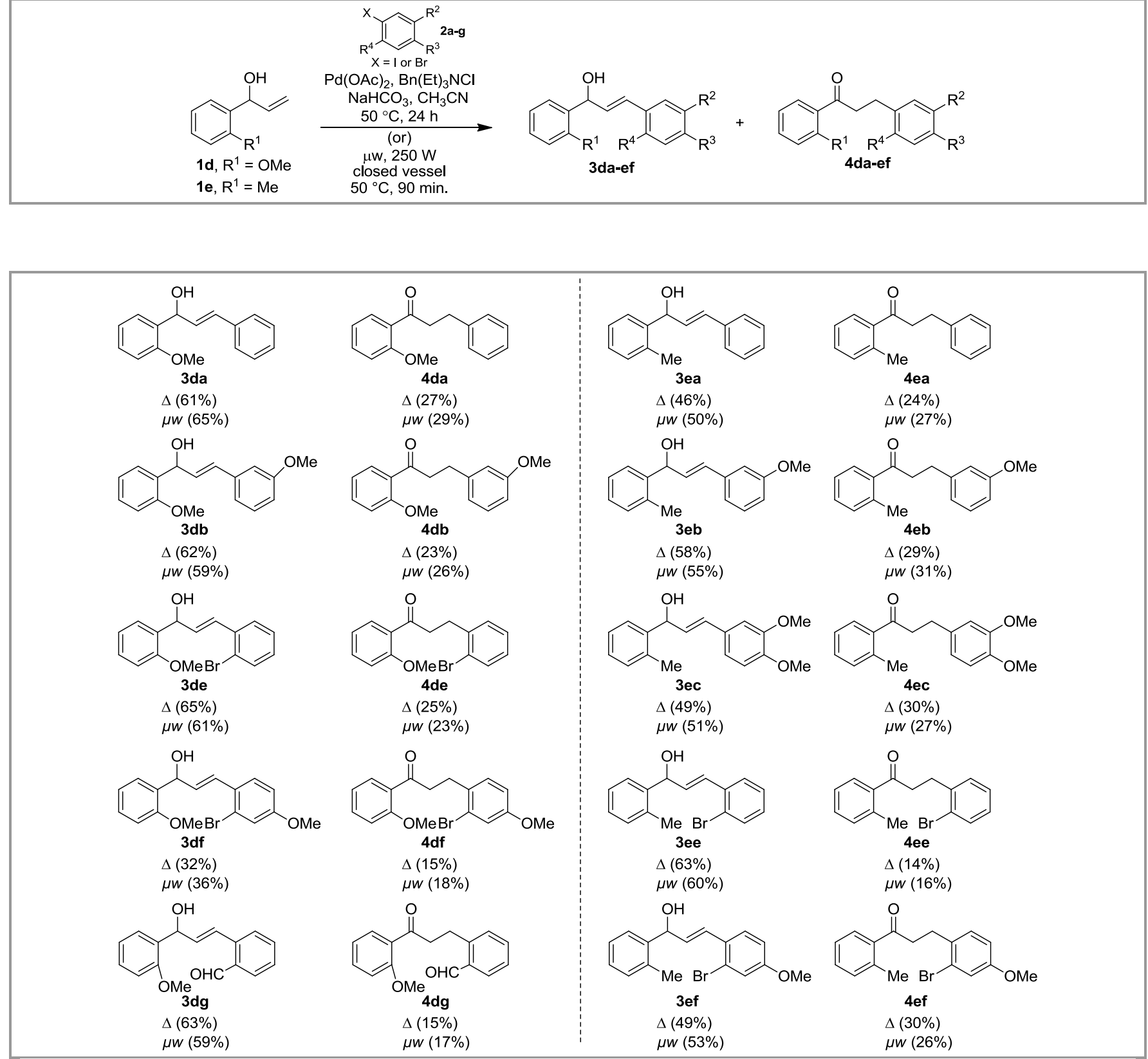

[a] Isolated yields of chromatographically pure products; for compounds $\mathbf{3}$ the first letter refers to the allylic alcohol part (1d-1e) whereas the second letter indicates the aromatic ring coming from the aryl halides $\mathbf{2 a - 2 g}$. 


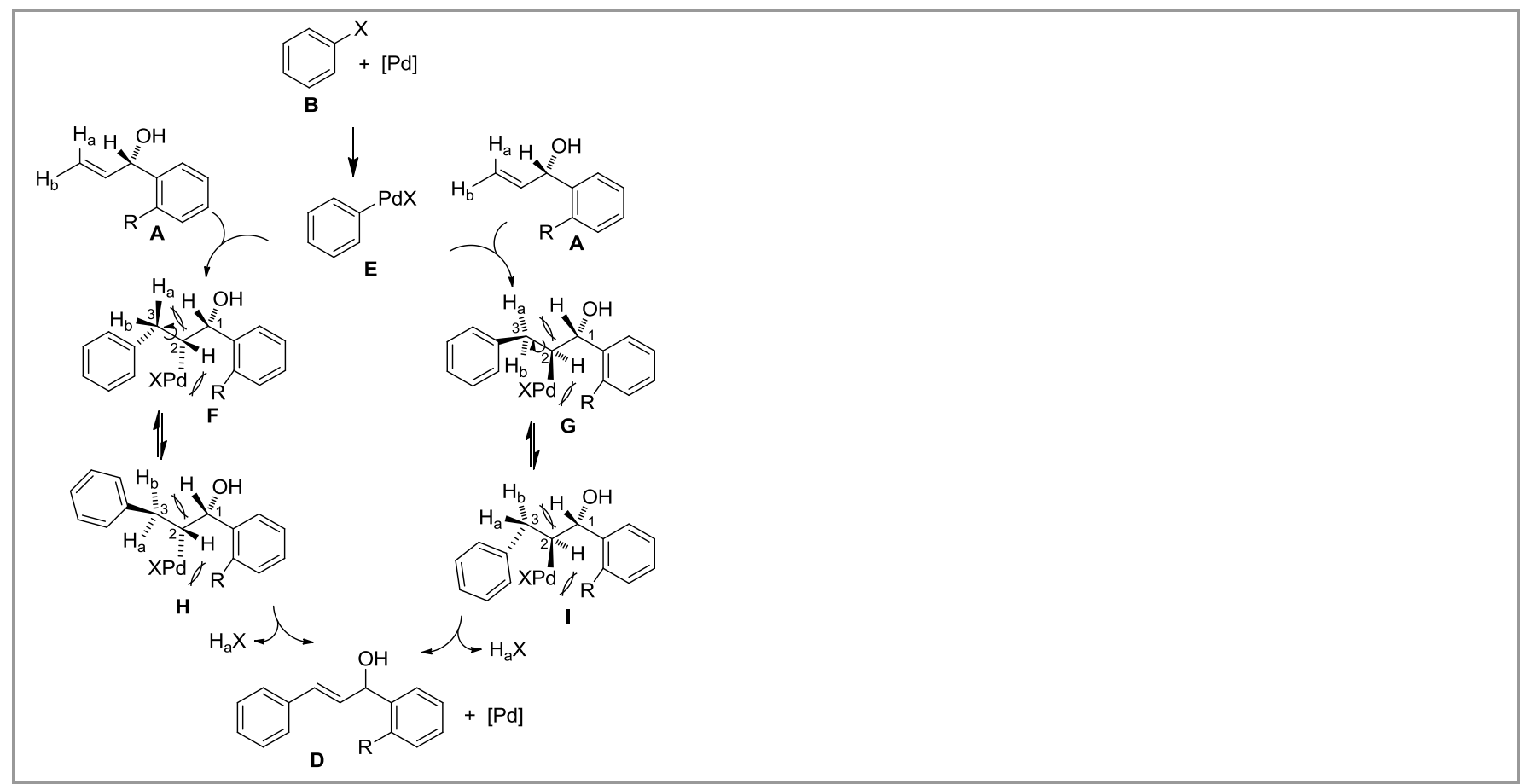

Scheme 2. Plausible mechanistic path, for the formation of $\beta$-arylallylicalcohol D. For simplicity, ligands are omitted.

Supporting Information for this article is available online at http://www.thieme-connect.com/ejournals/toc/synlett.

\section{References}

(1) a) Heck, R. F. J. Am. Chem. Soc. 1968, 90, 5526. b) Heck, R. F. Palladium Reagents in Organic Syntheses, Academic Press, London, 1985. c) Heck, R. F. Organic Reactions 1982, 27, 345.

(2) For selected reviews, see: a) Amy B. Dounay, A. B.; Overman, L. E. Chem. Rev. 2003, 103, 2945. b) Beletskaya, I. P.; Cheprakov, A. V. Chem. Rev. 2000, 100, 3009. c) Tietze, L. F.; Ila, H.; Bell, H. P. Chem. Rev. 2004, 104, 3453. d) Zeni G.; Larock, R. C. Chem. Rev. 2006, 106, 4644. e) Negishi, E.; Copéret, C.; Ma, S., Show-Yee Liou, S. -Y.; Liu, F. Chem. Rev. 1996, 96, 365.

(3) Melpolder, J. B.; Heck, R. F. J. Org. Chem. 1976, 41, 265.

(4) Chalk, A. J.; Magennis, S. A. J. Org. Chem. 1976, 41, 273.

(5) a) Jeffery, T. Tetrahedron Lett. 1991, 32, 2121. b) Jeffery, T. Tetrahedron Lett. 1990, 31, 6641. c) Jeffery, T. J. Chem. Soc., Chem. Commun. 1991, 324.

(6) For relevant topic, see review: Muzart, J. Tetrahedron 2005, 61, 4179.

(7) a) Tamaru, Y.; Yamada, Y.; Yoshida, Z. Tetrahedron 1979, 35, 329. b) Aslam, M.; Elango, V.; Davenport, K. G. Synthesis 1989, 869. c) Beller, M.; Zapf, A. Synlett 1998, 792. d) Bouquillon, S.; Ganchegui, B.; Estrine, B.; Hénin, F.; Muzart, J. J. Organomet. Chem. 2001, 634, 153. e) Caló, V.; Nacci, A.; Monopoli, A.; Spinelli, M. Eur. J. Org. Chem. 2003, 1382. f) Jeffery, T. J. Chem. Soc., Chem. Commun. 1984, 1287. g) Reymond, J.-L.; Jahangiri, C. K.; Stoudt, C.; Lerner, R. A. J. Am. Chem. Soc. 1993, 115 , 3909. h) Reymond, J.-L.; Chen, Y. J. Org. Chem. 1995, 60, 6970. i) Kumareswaran, R.; Vankar, Y. D. Synth. Commun. 1998, 28, 2291. j) Larock, R. C.; Yum, E. K.; Yang, H. Tetrahedron 1994, 50, 305. k) Basavaiah, D.; Muthukumaran, K. Tetrahedron 1998, 54, 4943. 1) Ferreira, B.R.V.; Pirovani, R. V.; Souza-Filho, L. G.; Coelho, F. Tetrahedron 2009, 65, 7712. m) Sidler, D. R.; Sager, J. W.; Bergan, J. J.; Wells, K. M.; M. Bhupathy, M.; Volante, R. P. Tetrahedron: Asymmetry 1997, 8, 161. n) Kim, J. M.; Kim, K. H.; Kim, T. H.; Kim, J. N. Tetrahedron Lett. 2008, 49, 7712. o) Ohno, H.; Okumura, M.; Maeda, S.; Iwasaki, H.; Ryutaro Wakayama, R.; Tanaka, T. J. Org. Chem. 2003, 68, 7722.

(8) For domino reactions, see: a) Dyker, G.; Thöne, A. J. Prakt. Chem. 1993, 341, 138. b) Dyker, G.; Kadzimirsz, D.; Henkel, G. Tetrahedron Lett. 2003, 44, 7905. c) Catellani, M.; Deledda, S.; Ganchegui, B.; Hénin, F.; Motti, E.; Muzart, J. J. Organomet. Chem. 2003, 687, 473. ) Dyker, G.; Grundt, P.; Markwitz, H.; Henkel, G. J. Org. Chem. 1998, 63, 6043.

(9) a) Tietze, L. F.; Kahle, K.; Raschke, T. Chem. Eur. J. 2002, 8, 401. b) Bruyére, D.; Bouyssi, D.; Balme, G. Tetrahedron 2004, 60, 4007. c) Satyanarayana, G.; Maier, M. E. Tetrahedron 2008, 64, 356. d) Satyanarayana, G.; Maier, M. E. J. Org. Chem. 2008, 73, 5410. e) Gibson (née Thomas), S. E.; Jones, J. O.; McCague, R.; Tozer, M. J.; Whitcombe, N. J. Synlett 1999, 954.

(10) On long chain allylic alcohols, see: a) Larock, R. C.; Leung, W.-Y.; Stolz-Dunn, S. Tetrahedron Lett. 1989, 30, 6629. b) Wong, Y.; Dong, X.; Larock, R. C. J. Org. Chem. 2003, 68, 3090. c) Satyanarayana, G.; Maichle-Mössmer, C.; Maier, M. E. Chem. Commun. 2009, 1571. d) Dyker, G.; Markwitz, H. Synthesis 1998, 1750. e) Berthiol, F.; Doucet, H.; Santelli, M. Synthesis 2005, 3589. f) Cropper, E. L.; Yuen, A. -P.; Agnes Ford, A.; White, A. J. P.; Hii, K. K. (Mimi). Tetrahedron 2009, 65, 525.

(11) For intramolecular Heck type reaction, see: a) Shi, L.; Narula, C. K.; Mak, K. T.; Kao, L.; Xu, Y.; Heck, R. F. J. Org. Chem. 1983, 48, 3894. b) Gaudin, J.-M. Tetrahedron Lett. 1991, 32, 6113. c) Kelly, S. A.; Foricher, Y.; Mann, J.; Bentley, J. M. Org. Biomol. Chem. 2003, 1, 2865. d) Kondo, K.; Sodeoka, M.; Mori, M.; Shibasaki, M. Tetrahedron Lett. 1993, 34, 4219. e) Kondo, K.; Sodeoka, M.; Mori, M.; Shibasaki, M. Synthesis 1993, 920. f) Dyker, G.; Grundt, P. Eur. J. Org. Chem. 1999, 323. g) Mal, S. K.; 
Ray, D.; Ray, J. K. Tetrahedron Lett. 2004, 45, 277. h) Anna Maria Zawisza, A. M.; Ganchegui, B.; Iván González, I.; Sandrine Bouquillon, S.; Roglans, A.; Hénin, F.; Muzart, J. J. Mol. Catal. A: Chem. 2008, 283, 240.

(12) For $\beta$-arylallylic alcohols synthesis, see: a) Tietze, L. F.; Görlitzer, J.; Schuffenhauer, A.; Hübner, M. Eur. J. Org. Chem. 1999, 1075. b) Kang, S.-K.; Lee, H.-W.; Jang, S.-B.; Kim, T.-H.; Pyun, S.-J. J. Org. Chem. 1976, 41, 2604. c) Grasa, G. A.; Singh, R.; Stevens, E. D.; Nolan, S. P. J. Organomet. Chem. 2003, 687, 269. d) Kang, S.-K.; Jung, K.-Y.; Park, C.-H.; Namkoong, E.-Y.; Kim, T.-H. Tetrahedron Lett. 1996, 36, 6287. e) Dyker, G.; Thöne, A. J. Prakt. Chem. 1993, 341, 138.

(13) a) Briot, A.; Baehr, C.; Brouillard, R.; Wagner, A.; Mioskowski, C. J. Org. Chem. 2004, 69, 1374. 